Jannah Munifatul, Hidayatullah M Furqon, Syaifullah Rony. Anthropometric and biomotor factors that determine the ability of field tennis service. Journal of Education, Health and Sport. 2021;11(7):167-174. eISSN 2391-8306. DOI http://dx.doi.org/10.12775/JEHS.2021.11.07.015

https://apcz.umk.pl/czasopisma/index.php/JEHS/article/view/JEHS.2021.11.07.015

https://zenodo.org/record/5136939

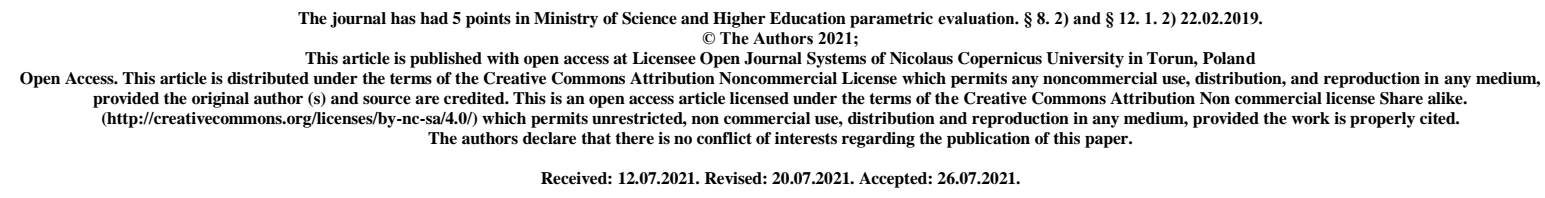

\title{
Anthropometric and biomotor factors that determine the ability of field tennis service
}

\author{
Munifatul Jannah', M Furqon Hidayatullah ${ }^{2}$, Rony Syaifullah ${ }^{3}$ \\ munifatuljannah97@gmail.com ${ }^{1}$, furqon@uns.ac.id ${ }^{2}$,ronysyaifullah@staff.uns.ac.id ${ }^{3}$ \\ Orcid id: 0000-0002-3598-18601 $, 0000-0001-8862-5862^{2}, 0000-0002-6480-8098^{3}$ \\ ${ }^{123}$ Postgraduate in Sports Science, Sebelas Maret University, Indonesia
}

\begin{abstract}
This study aims to analyze the Anthropometric and Biomotor Factors that Determine the Ability of Field Tennis Service on Achievement Development Students of FKOR UNS Surakarta. The method used in this study is a quantitative research approach using a confirmatory factor analysis design. Data were processed and analyzed using SPSS software version 22 and factor analysis using the Kaiser-Meyer-Olkin and Bartlett's Test. The population in this study were the 25 students of FKOR UNS tennis achievement coaching students. The sampling technique in this study used a total sampling technique. Data collection techniques using tests and measurements. Anthropometric factors that determine the ability to serve in tennis are weight with a value of 0.695 , height with a value of 0.661 and arm length with a value of 0.628 . The biomotor factors that determine the ability to serve in tennis are arm muscle power with a value of 0.863 and eye-hand coordination with a value of 0.653 . Based on the results of the second analysis, it was found that the five variables had communalities values $\mathrm{p}>0.5$. So it can be concluded that the greater the value of the communalities of these factors will provide benefits to students in coaching tennis achievements in serving tennis.
\end{abstract}

Key words: Anthropometry, Biomotor, Serviceability, Tennis Court 


\section{Introduction}

Tennis is a sport that is very popular and very popular in the community (Ade Ros, 2015). Court tennis is also a fun little ball game (Mashuri, 2019). The game of court tennis uses a racket to hit the ball and is usually played single or in pairs of two players each (Widiyatmoko et al., 2021). This sport has no age limit, everyone can do and enjoy the game of tennis (Rahmat Trisnawan \& Subagio, 2018). In order to be able to play tennis, a regular training process is needed (Kiki Riski Dinova, Muhammad Jafar, 2016). Practice with the right method can make a good mastery of basic techniques (Amni et al., 2019). The basic techniques of playing tennis should be mastered by the players in order to play well and achieve (Tarihoran \& Mahmuddin, 2020).

Many factors are needed in practice in order to play tennis well. One of the factors that support the achievement of tennis achievements is the mastery of technique and tactics of stroke (Arisman, 2018). The types of tennis strokes are groundstroke, serve, volley and overheadstroke or smash (Ngatman \& Sulistyatna, 2017).

Serving is one of the basic techniques in the game of tennis (Kardiawan et al., 2018). The serve is no longer considered the start of the game, but is the first form of attack in the match (Zoki \& Saputra, 2018). To improve the ability to hit the serve need proper and correct practice (Setyawan \& Irwansyah, 2019). Good physical ability is also an important factor (Kusuma et al., 2019). If the player does not have good physical ability in serving strokes, it will be difficult to get the right and optimal service strokes (Pujianto et al., 2019). In tennis, a serve is used as the first stroke to trouble an opponent (Gatot Margisal Utomo \& Daru Cahyono, 2020). It takes the strength and speed of the racket swing as well as the ability to control the ball so as to produce points (Kurdi \& Qomarrullah, 2020).

Anthropometry is also an important factor in sports achievement (Wibowo \& Hakim, 2019). Anthropometry is concerned with measuring and measuring the dimensions of the human body (Utami, 2016). The field of anthropometry includes various measurements of the human body such as weight, position when standing, when stretching the arms, body circumference, leg length and so on (Wahyudhi \& Iskandar, 2017). To carry out the service there are various anthropometric parts that are dominant in it. By having an ideal body, you will be able to carry out better, more effective and efficient service techniques (Elce et al., 2017).

Every biomotor abilities play an important role in sports activities, including mastering the basic technical skills of court tennis service (Diker et al., 2017). Biomotor ability plays a role in mastering the basic technical skills of tennis service, because in the biomotor consists of several components of physical condition which are very important to master the basic technique of serving in the game of tennis (Zirhli \& Demirci, 2020). Because when serving in a tennis game, a service certainly involves or requires good physical condition. Based on this, it illustrates that, to perform a tennis service technique, several biomotor components are needed. Based on all the components of the physical condition that have been mentioned, their maintenance and improvement cannot be separated from one another, so that an athlete's achievement in various sports can increase.

Anthropometric and biomotor factors can support the ability to serve tennis, because when doing service movements there are anthropometric and biomotor parts including: body weight, height, arm length, leg length, grip strength, eye-hand coordination, togok flexibility and power. arm muscle. These factors are a requirement to achieve achievement in the field of tennis. However, it is not yet known which part of the dominant anthropometric and biomotor factors with court tennis service ability. To find out, it is necessary to study and research in more depth, both theoretically and practically through anthropometric and biomotor tests and measurements on the ability to serve tennis in the field.

\section{Methods}

The method used in this study is a quantitative research approach using a confirmatory factor analysis design. Data were processed and analyzed using SPSS software version 22 and factor analysis using the Kaiser-Meyer-Olkin and Bartlett's Test. The population in this study were the 25 students of FKOR UNS tennis achievement coaching students. The sampling technique in this study used a total sampling technique. Data collection techniques using tests and measurements.

\section{Results and Discussion}

a. Data Description 
Table 1. Statistical description of anthropometric and biomotor factors that determine the ability to serve tennis in the field tennis performance coaching students of FKOR UNS.

Descriptive Statistics

\begin{tabular}{l|l|l|l|l|l}
\hline & $\mathrm{N}$ & Minimum & Maximum & Mean & Std. Deviation \\
\hline Weight & 25 & 53 & 91 & 69.00 & 9.475 \\
\hline Heght & 25 & 167 & 181 & 173.64 & 3.510 \\
\hline Sleeve length & 25 & 69 & 82 & 74.36 & 3.402 \\
\hline Leg length & 25 & 96 & 108 & 100.56 & 3.280 \\
\hline Grip strength & 25 & 29.6 & 55.0 & 45.460 & 7.2495 \\
\hline Eye-Hand coordination & 25 & 10 & 19 & 13.60 & 2.466 \\
\hline Togok flexibility & 25 & 40 & 69 & 58.80 & 7.405 \\
\hline Arm muscle power & 25 & 3.50 & 4.82 & 4.0944 & .43650 \\
\hline Serve skill tenis & 25 & 14 & 57 & 42.12 & 11.914 \\
\hline Valid N (listwise) & 25 & \multicolumn{5}{|l}{} & \\
\hline
\end{tabular}

Resourcer : Primary data (2021)

b. Analysis Prerequisite Test

1) Normality Test

In this study, the normality test was carried out using the One-Sample Kolmogorov-Smirnov Test method with the conditions that Ho: the population was normally distributed and Ha: the population was not normally distributed. The population is known to be normally distributed if the probability value $>=0.05$ then Ho is accepted. The population is known to be not normally distributed if the probability value is $<0.05$ then Ho is rejected. The following describes the results of the normality test of the variables:

Table 2. Summary of normality test results

\begin{tabular}{l|l|l|l|l}
\hline Variabel & N & Asymp. Sig (2-tailed) & Probabilitas & Conclusion \\
\hline Weight (X1) & 25 & 0.200 & 0,05 & data is normally distributed \\
\hline Height (X2) & 25 & 0.200 & 0,05 & data is normally distributed \\
\hline Sleeve length (X3) & 25 & 0.200 & 0,05 & data is normally distributed \\
\hline Leg length (X4) & 25 & 0.068 & 0,05 & data is normally distributed \\
\hline Grip strength (X5) & 25 & 0.200 & 0,05 & data is normally distributed \\
\hline Eye-hand coordination (X6) & 25 & 0.200 & 0,05 & data is normally distributed \\
\hline Togok flexibility (X7) & 25 & 0.200 & 0,05 & data is normally distributed \\
\hline Arm muscle power (X8) & 25 & 0.138 & 0,05 & data is normally distributed \\
\hline Serve skill tenis (Y) & 25 & 0.063 & 0,05 & data is normally distributed \\
\hline
\end{tabular}

Resource : Primary data (2021)

2) Linearity Test

The next step is to do a linearity test using the ANOVA method to find out whether each component variable has a linear relationship or not with a significance level of 0.05 as follows:

Table 3. Summary of linearity test results

\begin{tabular}{l|l|l|l}
\hline Variable & Linearity & Sig & Conclusion \\
\hline $\mathrm{X}_{1} \mathrm{Y}$ & 0.327 & 0,05 & linear \\
\hline $\mathrm{X}_{2} \mathrm{Y}$ & 0.202 & 0,05 & linear \\
\hline $\mathrm{X}_{3} \mathrm{Y}$ & 0.184 & 0,05 & linear \\
\hline $\mathrm{X}_{4} \mathrm{Y}$ & 0.347 & 0,05 & linear \\
\hline $\mathrm{X}_{5} \mathrm{Y}$ & 0.137 & 0,05 & linear \\
\hline $\mathrm{X}_{6} \mathrm{Y}$ & 0.261 & 0,05 & linear \\
\hline $\mathrm{X}_{7} \mathrm{Y}$ & 0.271 & 0,05 & linear \\
\hline $\mathrm{X}_{8} \mathrm{Y}$ & 0.236 & 0,05 & linear \\
\hline
\end{tabular}


Resource : Primary data (2021)

3) Factor Analysis

a) Factor analysis I

Table 4. The results of KMO and Bartlett's Test I analysis of anthropometric and biomotor factors that determine the ability to serve tennis in tennis students of FKOR UNS

\begin{tabular}{|c|c|c|}
\hline \multicolumn{3}{|l|}{ KMO and Bartlett's Test } \\
\hline \multicolumn{2}{|c|}{ Kaiser-Meyer-Olkin Measure of Sampling Adequacy. } & .574 \\
\hline \multirow[t]{3}{*}{ Bartlett's Test of Sphericity } & Approx. Chi-Square & 98.488 \\
\hline & $\mathrm{df}$ & 28 \\
\hline & Sig. & .000 \\
\hline
\end{tabular}

Resource : Primary data (2021)

Based on the results of the analysis above, the Kaiser-Meyer-Olkin Measure of Sampling Adequacy value is $0.574>0.5$ and the significance value is $0.000<0.05$ so it can be concluded that the variable components in the study are significant and can be processed to the next stage.

Table 5. The results of anti-image matrices correlation I anthropometric and biomotor factors that determine the ability to serve tennis in tennis students of FKOR UNS.

\begin{tabular}{|c|c|c|c|c|c|c|c|c|}
\hline $\begin{array}{l}\text { Anti-image } \\
\text { correlation }\end{array}$ & $\begin{array}{l}\text { Weight } \\
\text { (X1) }\end{array}$ & $\begin{array}{l}\text { Height } \\
\text { (X2) }\end{array}$ & $\begin{array}{l}\text { Sleeve } \\
\text { length } \\
\text { (X3) }\end{array}$ & $\begin{array}{l}\text { Leg } \\
\text { length } \\
\text { (X4) }\end{array}$ & $\begin{array}{l}\text { Grip } \\
\text { strength } \\
\text { (X5) }\end{array}$ & $\begin{array}{l}\text { Eye-hand } \\
\text { coordination } \\
\text { (X6) }\end{array}$ & $\begin{array}{l}\text { Togok } \\
\text { flexibility } \\
\text { (X7) }\end{array}$ & $\begin{array}{l}\text { Arm muscle } \\
\text { power }(\mathrm{X} 8)\end{array}$ \\
\hline Weight (X1) & $.695^{a}$ & .123 & .026 & -.157 & -.008 & -.211 & .104 & -.083 \\
\hline Height (X2) & .123 & $.661^{a}$ & -.921 & .097 & .087 & .051 & -.207 & .069 \\
\hline $\begin{array}{l}\text { Sleeve } \\
\text { length (X3) }\end{array}$ & .026 & -.921 & $.628^{a}$ & -.189 & -.106 & -.207 & .252 & -.297 \\
\hline $\begin{array}{ll}\text { Leg } & \text { length } \\
\text { (X4) } & \end{array}$ & -.157 & .097 & -.189 & $.392^{\mathrm{a}}$ & .452 & .231 & -.659 & .172 \\
\hline $\begin{array}{l}\text { Grip strength } \\
\text { (X5) }\end{array}$ & -.008 & .087 & -.106 & .452 & $.229^{a}$ & .343 & -.592 & .086 \\
\hline $\begin{array}{l}\text { Eye-hand } \\
\text { coordination } \\
\text { (X6) }\end{array}$ & -.211 & .051 & -.207 & .231 & .343 & $.653^{a}$ & -.421 & .040 \\
\hline $\begin{array}{l}\text { Togok } \\
\text { flexibility } \\
\text { (X7) }\end{array}$ & .104 & -.207 & .252 & -.659 & -.592 & -.421 & $.387^{a}$ & -.168 \\
\hline $\begin{array}{l}\text { Arm muscle } \\
\text { power (X8) }\end{array}$ & -.083 & .069 & -.297 & .172 & .086 & .040 & -.168 & $.863^{a}$ \\
\hline
\end{tabular}

Based on the anti-image matrix correlation table above, it shows that there are two variables that have a measury of sampling adequacy (MSA) value below 0.5, namely leg length with a value of 0.392, grip strength with a value of 0.229 and togok flexibility with a value of 0.387 . These variables will be reduced and declared unfit for further analysis. The next step is to reduce the variables using factor analysis II by excluding the 
variables of arm length, grip strength and togok flexibility because it has a measury of sampling adequacy (MSA) value below 0.5 so it does not meet the feasibility. After the reduction is done, then another factor analysis is carried out with the details of the results as follows:

b) Factor analysis II

Table 6. Results of KMO and Bartlett's Test II analysis of anthropometric and biomotor factors that determine the ability to serve tennis in the field tennis performance coaching students of FKOR UNS.

\section{KMO and Bartlett's Test}

\begin{tabular}{l|l|l}
\hline \multicolumn{2}{l|}{ Kaiser-Meyer-Olkin Measure of Sampling Adequacy. } & .722 \\
\hline \multirow{2}{*}{ Bartlett's Test of Sphericity } & Approx. Chi-Square & 79.313 \\
\cline { 2 - 3 } & Df & 10 \\
\cline { 2 - 3 } & Sig. & .000 \\
\hline
\end{tabular}

Resource : Primary data (2021)

Based on the results of the analysis in the table above for the 5 variables, the Kaiser-Meyer-Olkin Measure of Sampling Adequacy value is 0.722 and a significance value is 0.000 . If the Kaiser-Meyer-Olkin Measure of Sampling Adequacy value is $>0.5$ and the significance value is $<0.05$, then there is a strong relationship. The table above shows that the Kaiser-Meyer-Olkin Measure of Sampling Adequacy value is $0.722>0.5$ and the significance value is $0.000<0.05$ so it can be concluded that the 5 component variables in the study are significant and can be processed to the next stage.

Table 7. The results of anti-image matrices correlation II anthropometric and biomotor factors that determine the ability to serve tennis in tennis students of FKOR UNS.

\begin{tabular}{l|l|l|l|l|l}
\hline Anti-image correlation & $\begin{array}{l}\text { Weight } \\
(\mathrm{X} 1)\end{array}$ & $\begin{array}{l}\text { Height } \\
(\mathrm{X} 2)\end{array}$ & $\begin{array}{l}\text { Sleeve } \\
\text { length } \\
(\mathrm{X} 3)\end{array}$ & $\begin{array}{l}\text { Eye-hand } \\
\text { coordination } \\
(\mathrm{X} 4)\end{array}$ & $\begin{array}{l}\text { Arm muscle } \\
\text { power (X5) }\end{array}$ \\
\hline Weight (X1) & $\mathbf{. 7 6 5}^{\mathbf{a}}$ & .147 & -.009 & -.208 & -.056 \\
\hline Height (X2) & .147 & $\mathbf{. 6 5 7}$ & -.921 & -.040 & .039 \\
\hline Sleeve length (X3) & -.009 & -.921 & $\mathbf{. 6 4 8}^{\mathbf{a}}$ & -.127 & -.264 \\
\hline Eye-hand coordination (X4) & -.208 & -.040 & -.127 & $\mathbf{. 9 1 0}$ & -.026 \\
\hline Arm muscle power (X5) & -.056 & .039 & -.264 & -.026 & $\mathbf{. 9 3 0}^{\mathbf{a}}$ \\
\hline
\end{tabular}

Measures of Sampling Adequacy (MSA)

Resource : Primary Data (2021)

The results of the analysis in the anti-image matrix correlation table II show that the five variables, namely weight have a value of 0.765 , height has a value of 0.657 , arm length has a value of 0.648 , eye-hand coordination has a value of 0.910 , and arm muscle power has a value of 0.930 . The value of the five variables has a value of Measure of Sampling Adequacy $>0.5$ so it can be concluded that it meets the feasibility for the next stage of analysis. The data from the anti-image matrix correlation analysis of the seven variables were declared feasible and then the testing phase was carried out using the extraction process with the principal component analysis method to produce the communalities values which are presented in the table as follows: 
Table 8. The results of communalities analysis of anthropometric and biomotor factors that determine the ability to serve tennis in the field tennis students of FKOR UNS.

\begin{tabular}{l|l|l}
\hline Communalities & Initial & Extraction \\
\hline Weight & 1.000 & .888 \\
\hline Height & 1.000 & .899 \\
\hline Sleeve length & 1.000 & .914 \\
\hline Eye-hand coordination & 1.000 & .648 \\
\hline Arm muscle power & 1.000 & .615 \\
\hline
\end{tabular}

Extraction Method: Principal Component Analysis.

Resource : Primary data (2021)

The results of communalities in the table above reflect the values provided that the greater the value of the communalities of a variable, the closer it is to the variables formed. From these results, the largest dimension role is arm length variable with a value of 0.914 and the smallest dimension role is arm muscle power with a value of 0.615 . The five variables have communalities values $p>0.5$ so it can be concluded that they can be tested using further factor analysis.

To find out the contribution of each variable to each component, a rotation process is carried out to produce a component matrix which will be presented in the following table:

Table 9. The results of the rotated component matrix analysis of anthropometric and biomotor factors that determine the ability to serve tennis in the field tennis performance coaching students of FKOR UNS.

\begin{tabular}{l|l|l}
\hline Rotated Component Matrix & \multicolumn{2}{l}{} \\
\hline & Component \\
\cline { 2 - 3 } & 1 & 2 \\
\hline Weight & -.131 & .933 \\
\hline Height & .902 & -.293 \\
\hline Sleeve length & .919 & -.262 \\
\hline Eye-hand coordination & .735 & .329 \\
\hline Arm muscle power & .777 & -.110 \\
\hline
\end{tabular}

Resource : Primary data (2021)

Based on the results of the hypothesis test above regarding the analysis of anthropometric and biomotor factors that determine the ability to serve tennis in the field tennis performance coaching students of FKOR UNS, it is known that there are 3 variables, namely the factor of leg length, grip strength and flexibility of the togok that do not meet eligibility and must be eliminated because has a value of Measure of Sampling Adequacy >0.5. While the other 5 variables, namely weight, height, arm length, hand-eye coordination and arm muscle power met the feasibility and could be analyzed in the next stage. The following are the results of the analysis of the components of anthropometric and biomotor factors that determine the ability to serve in tennis:

1. Weight

Body weight is one of the important components in supporting the tennis service ability. Players who have an ideal body weight have an advantage in serving tennis courts. This is supported by the fact in research that players who have an ideal body weight have a higher success in serving tennis. The results of the communalities value on the weight factor obtained a value of 0.888 which means that body weight has a percentage of $88 \%$ of the role of the factor.

2. Height 
Height is an important component in supporting the ability to serve tennis courts. Players who have the ideal height have an advantage in serving tennis courts. This is supported by the fact in research that players who have ideal height have higher success in serving tennis. The results of the communalities value on the height factor obtained a value of 0.899 which means that height has a percentage of $89 \%$ of the role of the factor.

3. Sleeve length

Arm length is one of the anthropometric components of the body that supports the ability to serve in tennis. It can be seen from the analysis that arm length has the highest correlation value compared to other factors. The value of communalities in the arm length factor is obtained by a value of 0.914 which means that the arm length has a percentage of $91 \%$ of the role of the factor. Arm length has an advantage in serving court tennis because it is supported by the arm length factor affecting the swing speed when hitting the ball so that the ball can go faster. In other words, an athlete who has long arms and is supported by other biomotor factors such as arm muscle power will produce a more perfect serve.

4. Eye-hand coordination

Eye-hand coordination also plays a role in contributing to the game of tennis. Eye-hand coordination is one of the elements that must be possessed by a tennis athlete. The value of communalities in the eye-hand coordination factor is obtained a value of 0.648 which means that eye-hand coordination has a percentage of $64 \%$ of the role of the factor. One of the contributions or benefits of eye-hand coordination is helping when bouncing the ball during serve and targeting accuracy. So that athletes can contribute better movements in serving tennis courts.

5. Arm muscle power

Arm muscle power in court tennis is used to perform service movements. There are several advantages to an athlete who has arm muscle power, one of which is the ability to control the severity of the blow or fall near the result of the service. So that by having good arm muscle power, a tennis athlete can direct and adjust the speed of the service ball as desired. The value of communalities in the arm muscle power factor is 0.615 , which means that the arm muscle power has a percentage of $61 \%$ of the role of the factor. In addition, arm muscle power can also support an athlete's achievement because it is one of the basic components of a biomotor.

\section{Conclusion}

Anthropometric factors that determine the ability to serve in tennis are weight with a value of 0.695 , height with a value of 0.661 and arm length with a value of 0.628 . The biomotor factors that determine the ability to serve in tennis are arm muscle power with a value of 0.863 and eye-hand coordination with a value of 0.653 . Based on the results of the second analysis, it was found that the five variables had communalities values $>0.5$. So it can be concluded that the greater the value of the communalities of these factors will provide benefits to students in coaching tennis achievements in serving tennis.

\section{References}

Ade Ros, R. (2015). Pengembangan Model Pembelajaran Voli Forehand Tenis Lapangan. Jurnal Paedagogik Keolahragaan, 1(1), 20-28.

Amni, H., Sulaiman, I., \& Hernawan, H. (2019). Model Latihan Keterampilan Groundstroke Pada Cabang Olahraga Tenis Lapangan. Jurnal Terapan Ilmu Keolahragaan, 4(2), 91-98. https://doi.org/10.17509/jtikor.v4i2.18968

Arisman, A. (2018). Kontribusi Kekuatan Genggaman terhadap Akurasi Servis Flat Atlet Tenis Lapangan Universitas Negeri Padang (PTL UNP). Jurnal Olahraga, 4(1), 24-30. https://doi.org/10.37742/jo.v4i1.80

Diker, G., Zileli, R., Özkamç1, H., \& Ön, S. (2017). Evaulation of Some Physiological and Biomotor Features of Young Tennis Players. International Journal of Sports Exercise and Training Sciences, 3(1), $25-32$. https://doi.org/10.18826/useeabd.296396

Elce, A., Cardillo, G., Ventriglia, M., Giordano, C., Amirante, F., Mazza, G., Sangiorgio, A., \& Martiniello, L. (2017). Anthropometric characteristics of young Italian tennis players. Journal of Human Sport and Exercise, 12(3), 651-658. https://doi.org/10.14198/jhse.2017.123.09

Gatot Margisal Utomo, \& Daru Cahyono. (2020). Analisis Gerak Teknik Dasar Dalam Melakukan Pukulan Servis Pada Atlet Tenis Lapangan Usia 13-15 Tahun Di Semen Indonesia Tenis Akademi. Journal STAND : Sports Teaching and Development, 1(1), 22-26. https://doi.org/10.36456/j-stand.v1i1.2329

Kardiawan, I. K. H., Satyawan, I. M., \& Ariawan, K. U. (2018). Pengembangan Perangkat Alat Ukur Kekuatan Servis Bola Tenis Lapangan Berbasis Sensor Digital. In Seminar Nasional Riset Inovatif 2018 (pp. 183-185).

Kiki Riski Dinova, Muhammad Jafar, K. (2016). Hubugan Koordinasi Mata Tangan terhadap Keterampilan Tenis Lapangan pada Mahasiswa Program Studi Penjaskesrek FKIP UNSYIAH Angkatan 2012. Jurnal Ilmiah Mahasiswa Pendidikan Jasmani, Kesehatan Dan Rekreasi, 2(1), 17-24. 
Kurdi, K., \& Qomarrullah, R. (2020). Hubungan Kecepatan Reaksi Tangan dan Koordinasi Mata Tangan Pada Servis Tenis Lapangan Mahasiswa Universitas Cenderawasih. Jurnal Terapan Ilmu Keolahragaan, 5(1), $22-27$. https://doi.org/10.17509/jtikor.v5i1.25060

Kusuma, I. A., Yulianto, R., \& Ardianzah, A. (2019). Perbedaan Pengaruh Metode Pembelajaran Direct Dan Indirect Terhadap Peningkatan Kemampuan Servis Tenis Lapangan Tahun 2019 (Studi Eksperimen Pada Mahamahasiswa Putra Semester IV Fakultas Keguruan Dan Ilmu Pendidikan Jurusan PKO UTP Surakarta). Jurnal Ilmiah Spirit, 19(2), 13-25. https://doi.org/10.36728/jis.v19i2.949

Mashuri, H. (2019). Evaluasi Program Pembinaan Tenis Lapangan PELTI Kota Palembang. JOSSAE : Journal of Sport Science and Education, 4(1), 7-13. https://doi.org/10.26740/jossae.v4n1.p7-13

Ngatman, N., \& Sulistyatna, E. (2017). Tingkat Kemampuan Forehand Groundstroke Dan Backhand Groundstroke Siswa Sekolah Tenis Menoreh Tennis Club, Handayani Tennis Club Dan Bantul Tennis Camp. Jorpres (Jurnal Olahraga Prestasi), 13(1), 1-9. https://doi.org/10.21831/jorpres.v13i1.12880

Pujianto, D., Sutisyana, A., \& Arwin. (2019). Pemanfaatan Video Game Virtual Tenis untuk Meningkatkan Hasil Belajar Servis Tenis Lapangan Mahasiswa Pendidikan Jasmani Fakultas Keguruan dan Ilmu Pendidikan Universitas Bengkulu. Jurnal Ilmu Keolahragaan, 18(2), 79-83.

Rahmat Trisnawan, G., \& Subagio, I. (2018). Pembinaan Prestasi Cabang Olahraga Tenis Jawa Timur. Jurnal Prestasi Olahraga, 1(3), 28-35.

Setyawan, T., \& Irwansyah, I. (2019). Pengembangan Model Servis Pembelajaran Tenis Lapangan Mahasiswa PJKR IKIP Budi Utomo. Jendela Olahraga, 4(2), 70-75. https://doi.org/10.26877/jo.v4i2.3725

Tarihoran, D., \& Mahmuddin, M. (2020). Kontribusi Latihan Hand Grip dan Latihan Back-Up Terhadap Servis Slice Pada Atlet Putra Komunitas Tenis Lapangan Unimed. Jurnal Prestasi, 4(2), 66-72. https://doi.org/10.24114/jp.v4i2.21451

Utami, N. W. A. (2016). Modul Antropometri. In Diklat/Modul Antopometri.

Wahyudhi, A. . B. S. W. ., \& Iskandar, H. (2017). Pengukuran Anthropometri Terhadap Status Kondisi Fisik Mahasiswa PJKR Untad Angkatan 2016. Tadulako Journal Sport Sciences and Physical Education, 7(2), 87100 .

Wibowo, E. T., \& Hakim, A. A. (2019). Profil Indeks Massa Tubuh Pada Atlet Tim Nasional Indonesia Pada Asian Games 2018. Jurnal Kesehatan Olahraga, 8(1), 131-140.

Widiyatmoko, F., Kusumawardhana, B., \& Imran, M. N. A. (2021). Perbandingan Gerak Elbow Extension dan Elbow Flexion Terhadap Akurasi Forehand Tenis Lapangan. Journal Sport Area, 6(1), 13-19. https://doi.org/10.25299/sportarea.2021.vol6(1).4229

Zirhli, O., \& Demirci, N. (2020). The Influence of functional training on biomotor skills in girl tennis players aged 10-12. Baltic Journal of Health and Physical Activity, 12(4), 33-45. https://doi.org/10.29359/bjhpa.12.4.04

Zoki, A., \& Saputra, Y. D. (2018). Pengaruh Mental Imagery Terhadap Penguasaan Keterampilan Dasar Forehand Groundstroke, Servis Flat, Dan Servis Slice Tenis Lapangan. BRAVO'S (Jurnal Prodi Pendidikan Jasmani \& Kesehatan), 6(2), 49-58. https://doi.org/10.26533/bravos.v6i2.743 